\title{
Spatial Analysis of Renewable Energy Sources
}

\author{
Marika KACARE ${ }^{*}$, Ieva PAKERE ${ }^{2}$, Armands GRĀVELSIN̦Š3${ }^{3}$, Dagnija BLUMBERGA ${ }^{4}$ \\ ${ }^{1-4}$ Institute of Energy Systems and Environment, Faculty of Electrical and Environmental Engineering, \\ Riga Technical University, Äzenes iela 12-K1, Rīga, LV-1048, Latvia
}

\begin{abstract}
Renewable energy sources are expanding opportunities for industrial development and can boost economic growth and create new jobs. In all European Union (EU) countries, including Latvia, it is possible to use renewable energy resources cost-effectively. The world is now at the beginning of the global energy transformation. Cost-effective renewable energy technologies provided an opportunity for sufficient development to reach ambitious climate targets of the EU Directive 2009/28/EC. Some systems are not only dependent on the interaction of many elements and dynamics over time, but they are also variable in space. In this context, energy production from local and renewable resources is one of the most relevant examples. It is characterized by many spatially variable elements, such as biomass availability, wind speed, solar radiation, location of power plants, transmission network infrastructure, energy demand, etc. It is crucial to explore the spatial distribution of resources to plan territorially-unified development of renewable energy and, consequently, promote efficient use of resources. This paper describes the data acquisition process of the spatial distribution of renewable energy sources. ArcGIS PRO and data collected from the various databases were used to describe the energy sectors according to resources, spheres of consumption and regions.
\end{abstract}

Keywords - Geographic Information Systems (GIS); regional planning; wind energy

\section{INTRODUCTION}

Synergies among renewable energy sources (RES), which contribute to the deployment of renewable energy technologies, have been identified in many technologies and sectors. RE technologies have evolved steadily over the past decade, so renewables have become competitive enough to meet the demands of the new generation. Moreover, electricity costs from RES continue to fall [1]. Various binding legislative documents oblige prioritizing RES and focus on green, local energy. Society cannot make this transition without estimating the available resources and understanding the links among many factors influencing the energy market [2]. The interdimensional environmental problems require a versatile approach considering all the variables. No model can do that thoroughly, but the closer one can get to that, the higher our chances to predict future scenarios.

As emphasized in the article [3], the inclusion of time and space as additional parameters is not enough for energy system modelling. Time and space must be integrated into the model better to understand the dynamics in terms of energy demand, availability and efficiency of traditional and renewable resources, energy infrastructure capacity and load, decentralized energy storage, and return on investment and cost-effectiveness. Geographic conditions are a critical factor that should not be overlooked when natural or social processes are observed.

\footnotetext{
* Corresponding author.

E-mail address: marika.kacare@edu.rtu.com
} 
Location and specific details are included in research on a larger scale, such as international or global-level differences. These aspects make a difference at the country level, too [4].

Meanwhile, simulations of structures that characterize the arrangement of system elements and their interrelationships receive very little attention in spatial system dynamics. The structural change model deals with the change of spatial structures over time and the processes that cause these changes. One example of this type of model is the land cover model. Land cover is determined by the properties of the Earth's surface and the subsoil, while natural and anthropogenic processes change these properties over time. Meanwhile, these processes are influenced by the spatial arrangement of the elements. Some modellers have introduced this type of feedback system into spatial system dynamics [2]. Still, currently available models primarily represent structures as a space of element relations, regardless of the absolute location of elements or without feedback between processes and systems [5].

At present, external assumptions about macro-level phenomena are mainly used to represent the energy system. The scale is one of the main prerequisites for estimating, for example, energy consumption over time [6]. Depending on the scale of the assessment, the hourly load curve can be very different, but at the same time, it can represent a smoothing effect in case of increasing the system limit. Depending on the spatial and temporal dimension, the number and type of elements chosen can have significant technical, financial and environmental impacts, determined by the infrastructure network, the selected alternatives, the technologies and other factors [7]. The reciprocal allocation of resources is linked to economic, political and social issues. These links must be considered when analysing the availability of resources and developing policies. Depending on the specific energy system in a given area, solutions to mitigate system risks and costs may include, for example, centralized rather than a distributed generation (or both) or the expansion of transmission networks rather than the introduction of several autonomous alternatives [8].

Using geographic data always leads to some uncertainty. All the common problems that users might have with the data, such as measurement error, errors in the compilation, overgeneralization, or lack of accurate definitions of terms, might occur. Every prediction should be followed by the assessment of the confidence limits of the assumption [9]. While using a geographical information system (GIS) is the best way to show spatial changes, there is a struggle regarding time changes. Managing the time visualization issue on the map often includes dividing the region into smaller areas, creating many basic units, similarly to cellular automata. The concept of basic units is continually discussed regarding land classifications to prevent defining the area as homogeneous. Another approach is to track the locations of independently moving objects, for example, the position of rocks depending on erosion. The third way is to show time changes as a sequence of simple snapshots of each period [9].

Several authors have analysed the renewable energy source potential in the Baltic States [10], [11]. It is generally assumed that there are no development possibilities for hydropower plants. The increase of RES is mostly expected from wind generation. Wind power plant development is possible in the future, depending on the internal regulations and the subsidy scheme. Construction of the transmission infrastructure near the Baltic Sea coast area would allow the development of offshore wind farms, which would increase the installed capacity of wind up to $600 \mathrm{MW}[12]$.

However, existing models mainly analyse the potential development of RES without considering country-specific regional differences. The particular research focuses on development on more detailed energy sector model by taking into account spatial differences. This publication addresses the lack of regional data in the energy sector that would assess geographic conditions and the specifics of each planning region of Latvia. The focus is on 
RES and the possible promotion of their usage. However, to do that, information about the current use of fossil fuel and tendencies is essential to see where the switch of the resources is possible and beneficial.

The aim is to present the methodology for in-depth regional analyses by considering data availability. The article presents main steps to collect the available regional data and calculate possible specific parameters for each region where the data is generalized and identify spatial barriers. Obtained data can be further used in different models to predict possible outcomes considering policy changes and increased usage of particular chosen energy sources. The spatial analyses of available energy sources, energy consumption, and different limitations allow for developing more country-specific models for future scenario analyses.

\section{Methods AND Methodology}

The article analyses the energy sector development in Latvia as a case study. There are five planning regions in Latvia - Kurzeme (KR), Latgale (LR), Riga (RR), Vidzeme (VR), and Zemgale planning region (ZR). Their competencies ensure regional development planning, coordination, cooperation between local governments and other public administration institutions.

\subsection{Determining RES Potential}

The primary resources for developing renewable energy are solar energy, wind energy, and bioresources - particularly wood biomass.

Data on the mean wind speed in statistical regions and municipalities have been compiled to characterize the spatial distribution of wind energy in Latvia. Data were obtained from the global Wind Atlas [13], which uses climatic wind data from 2008 to 2017, for wind speed at $100 \mathrm{~m}$ height, considering the current tendencies for wind turbine heights.

Data from European Commissions' Photovoltaic Geographical Information System was used to estimate the differences in solar irradiation between regions and municipalities [14]. Solar energy resources are represented with the data on annual irradiation at $35^{\circ}$ slope.

Considering the increasing demand for wood resources and considering the principles of the bioeconomy, according to which qualitative wood should be primarily used for high-value products, only low-quality wood is regarded as an energy resource for this research.

Data on the wood stock in municipalities were obtained from the 2019 forest statistics of the State Forest Service of the Republic of Latvia [15]. According to information provided in the literature, it is assumed that low-quality wood (branches, bark and foliage) represents $40 \%$ of the total wood stock [16].

Data on the sewage sludge production were obtained from the Latvian Environment, Geology and Meteorology Centre's (LVG̣MC) summary for 2018 [17]. The amount of sludge is expressed in dry matter.

Manure bio-fermentation is an increasingly used technology for bioenergy production worldwide. Theoretically, any type of manure or its organic by-products can be used for fermentation. Often companies operating in this field create a mixture of manure and other agricultural residues. Manure fermentation produces methane (55-65\%) and carbon dioxide $(35-40 \%)$ [18].

The amount of manure production was calculated from the data on the number of animals in municipalities in 2019 obtained from the public database of the Agricultural Data Centre of the Republic of Latvia [19]. Calculations are based on cattle and pig manure data, considering that these are the most common types of manure used for biogas production. 
To calculate the amount of manure produced, information on manure yield per animal provided in the national standard of the Ministry of Agriculture of the Republic of Latvia 'Manure extraction and management' was used [20]. The manure classification given in the document mentioned above was used to calculate the dry matter. According to this classification, solid litter manure is manure with at least $15 \%$ dry matter content. In contrast, liquid manure is any mixture of solid excrement, urine, and water with a 3 to $8 \%$ dry matter content. Calculations are based on the lowest possible values, $15 \%$ and $3 \%$, respectively.

Given that the most significant potential of hydropower in Latvia is already used [21], further expansion of hydro energy is not considered in this study.

Algae is also a potential resource for energy production; however, considering that algae resources are challenging to estimate and considering that algae can be cultivated, this type of resource is not spatially evaluated in this study. Another resource for fossil fuel elimination is municipal waste. However, given the limited availability of spatial data by type of waste and the fact that energy waste is still one of the most expensive types of energy production [22], waste resources are not spatially evaluated in this study.

\subsection{Determination of Energy Consumption and Generation}

The analyses of existing energy consumption and generation based on fuel consumption reports from the Latvian Environment, Geology and Meteorology Center (LVGMC) summarize the annual report on air quality [23]. The report is filled in by operators who have a permit to perform polluting activities [24].

By evaluating the resources consumed by these companies, it is possible to assess the consumption of resources for heat energy in the production and service sectors. All municipalities of Latvia were divided by the planning regions, and enterprises were divided into categories according to the NACE classification available [25]. Fuel consumption is considered in standard units, and it has been converted into energy units by assuming the average calorific value of each energy source.

\subsection{Available Area for the Wind Energy Generation}

After determining the available RES and energy consumption, the authors have identified the possible limitations for wind energy use. This resource is highly influenced by land availability for wind turbine installation. Authors assume that solar technologies could be mainly installed on the rooftops of buildings as well as they do not have so strict restrictions on installation in different types of areas; therefore, the land ability is not a primary barrier to using solar energy.

The data layers available from ArcGIS Pro and Envirotech from the GIS Latvia 10.2 database were used to determine the approximate area open in each planning region suitable for wind turbine installation.

The layers of buildings are taken from the GIS Latvia 9.2 database. Buffer zones were created around towns $(2 \mathrm{~km})$ and villages $(1 \mathrm{~km})$. All cities are available as a point layer. However, for the largest ones, the area is also available at the county layer. In these cases, a buffer was created around the city territory. A $500 \mathrm{~m}$ buffer is used for the building layer.

Houses outside villages were identified by exporting the data of all homesteads from the LGIA place name database and selecting existing objects. The table data is transferred to ArcGIS. A $500 \mathrm{~m}$ wide strip has been established for homesteads. Protection zones of water bodies and roads have been created based on the Protection Zones Law [26].

There is a $60 \mathrm{~m}$ wide buffer zone for roads on both sides of the centerline. Separate categories are not distinguished. According to the Protection Zones Law, this corresponds to 
the country's regional roads, a medium category. For railways, a $50 \mathrm{~m}$ wide zone was used. According to the protection zone law, a 100-meter-wide protection zone has been defined for all water bodies, corresponding to 25-100-hectare water bodies.

Watercourses are divided into categories. As large rivers in their widest places are also included in the water bodies layer, there are no places where the protection zone would be narrower than the river itself. Categories 60-80 are allocated $300 \mathrm{~m}$ wide zones corresponding to watercourses longer than $100 \mathrm{~km}$. Categories 20-50 have $100 \mathrm{~m}$ wide lanes corresponding to watercourses longer than 25 but shorter than $100 \mathrm{~km}$. River lines of category 10 have a $50 \mathrm{~m}$ wide protection zone on each bank (Table 1).

The new layers are grouped into one layer. The new single layer was cut using the contours of the planning regions.

TABle 1. Buffer Zones Applied to Determine the Area Suitable for the WIND ENERGY [26]

\begin{tabular}{lc}
\hline Object & Width, $\mathbf{m}$ \\
\hline Town & 2000 \\
Village & 1000 \\
Building & 500 \\
Homestead & 500 \\
Road & 60 \\
Railroad & 50 \\
Waterbody & 100 \\
Watercourses & \\
Category 60-80 & 300 \\
Category 20-50 & 100 \\
Category 10 & 50 \\
\hline
\end{tabular}

The area of the places that cannot be used for wind energy was calculated using the Calculate Geometry function.

\section{RESUlts}

This section presents the obtained results regarding the spatial profile of available RES, the main primary energy sources used in different sectors, and limitations for wind energy use in each region.

\subsection{Spatial Analyses of Available RES and Limitations for Wind Use}

Both onshore and offshore winds in Latvia are sufficient to use wind energy. The geographical location of Latvia and the coast of the Baltic Sea and the Gulf of Riga create suitable conditions for the use of wind energy. Latvia's flat terrain provides an opportunity to produce wind energy not only offshore but also onshore. Fig. 1 shows the distribution of the potentially available area for wind energy. It can be seen that around $70-80 \%$ of the total area would be suitable for wind turbine installation. It should be noted that forests are included in the available area. 


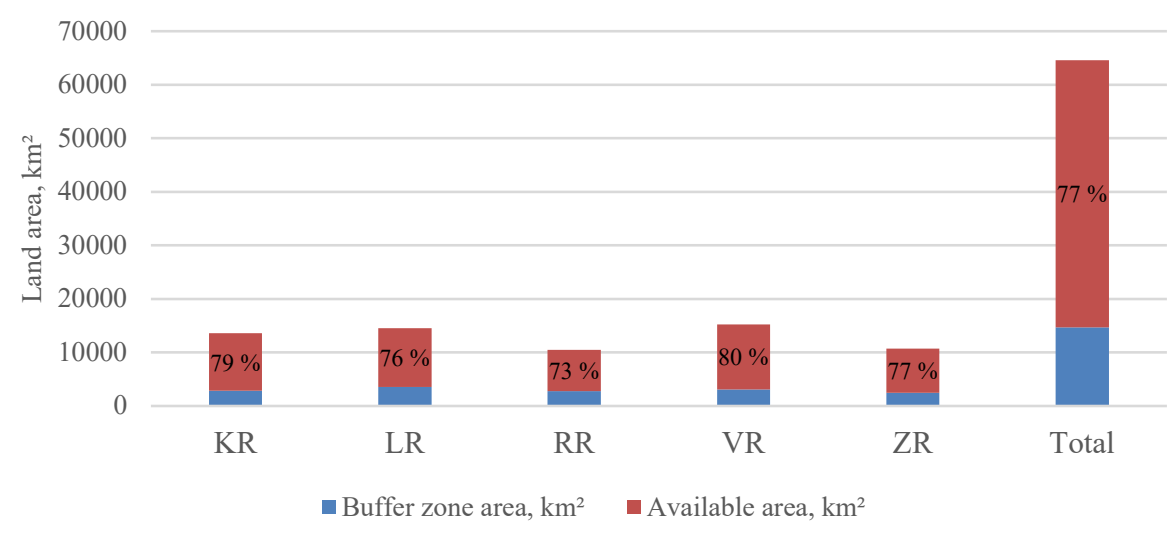

Fig. 1. Available area in the planning regions.

The detailed GIS maps for each resource have been prepared for in-depth analyses of spatial availability, which have been further aggregated into the regional scale (see example in Fig. 2). The highest mean wind speed is in the $\mathrm{KR}(7.2 \mathrm{~m} / \mathrm{s})$, the slightly lower speed is typical for ZR and LR $(7.1 \mathrm{~m} / \mathrm{s})$, while the lowest mean wind speed is in the VR and RR $(6.9 \mathrm{~m} / \mathrm{s})$.

In Latvia, the sunshine duration is about 1700-2000 hours a year (average of 1757 hours). The most extended period of sunshine is in July (approximately 300 hours), while the lowest - in December (about 25 hours or less than an hour a day) [17]. The highest solar irradiation is in the KR $\left(1180 \mathrm{kWh} / \mathrm{m}^{2} /\right.$ year $)$, while the lowest - in the VR $\left(1121 \mathrm{kWh} / \mathrm{m}^{2} /\right.$ year $)$. Municipalities with the lowest intensity of irradiation are concentrated in the VR.

The highest amount of low-quality wood is in the KR $\left(1908 \mathrm{t} / \mathrm{km}^{2}\right)$, RR $\left(1905 \mathrm{t} / \mathrm{km}^{2}\right)$ and $\operatorname{VR}\left(1895 \mathrm{t} / \mathrm{km}^{2}\right)$. When evaluating data at the municipal level, municipalities with the highest amounts of wood resources are concentrated in the RR and northern part of KR.

Most of the sewage sludge produced in Latvia is stored and not utilized. However, sludge is a promising RES. Biogas produced from sewage sludge can be used for heating, internal combustion engines, and electricity production [28]. Considering that the amount of produced sewage sludge depends on water consumption, evaluation at the regional level shows that a significantly large sludge amount was made in $\mathrm{RR}\left(29.47 \mathrm{t} / \mathrm{km}^{2}\right)$. In contrast, the smallest amount of sludge was produced in the KR $\left(0.17 \mathrm{t} / \mathrm{km}^{2}\right)$ and ZR $\left(0.18 \mathrm{t} / \mathrm{km}^{2}\right)$.

In 2017, a total amount of 451921 tons of manure was produced in Latvia in companies, which report to the national statistical report [17]. The amount of manure produced at the regional level shows at least twice as much manure in ZR as in other regions - 35.4 try matter $/ \mathrm{km}^{2}$ due to the high rate of agricultural processes. In other areas, the amount of manure was somewhat similar to one other.

The general distribution of the potential resources by the regions are showed in Table 2 . 




(a)

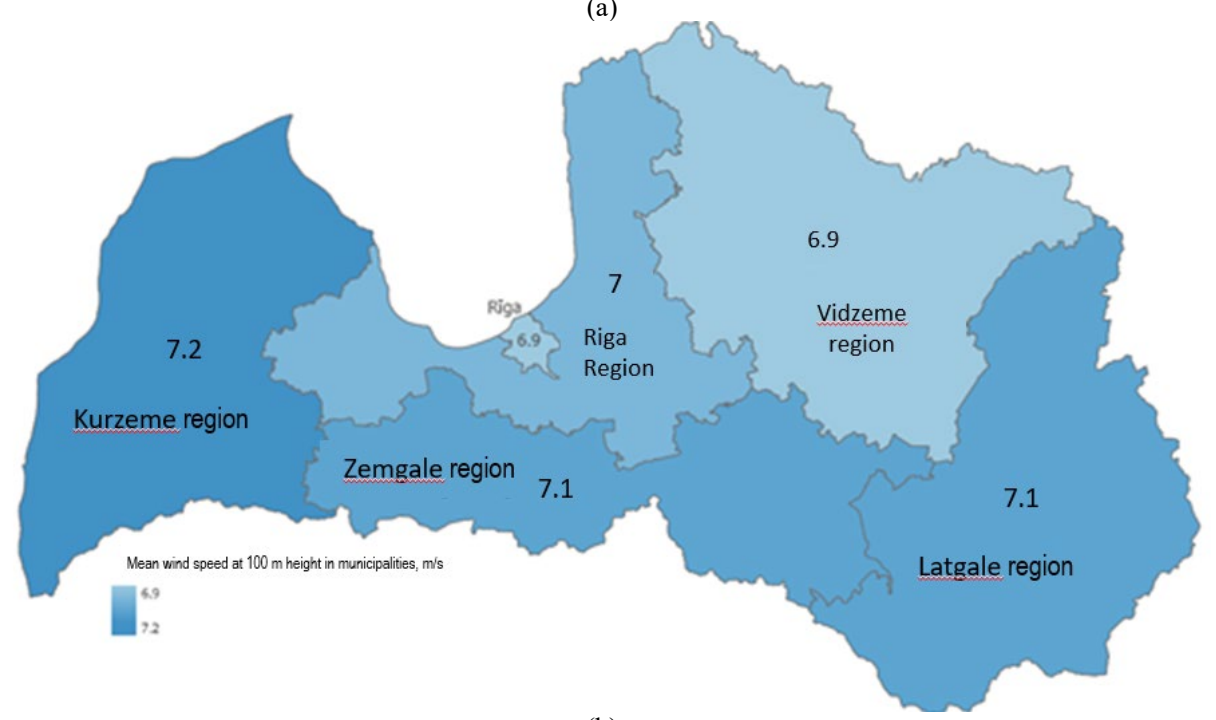

(b)

Fig. 2. Mean wind speed at $100 \mathrm{~m}$ height $(\mathrm{m} / \mathrm{s})$ in: a) municipalities; b) regions (GIS layout, [27]).

The spatial analyses show that the KR region has the highest potential for variable RES (solar and wind energy). Still, ZR has a high potential for agricultural waste resources (manure and straw). LR and VR have a lower potential of RES, which indicates the necessity to cooperate with other regions to increase the overall RES share. 
TABLE 2. OVERVIEW of AVERAge RES Potential [15], [17], [29]

\begin{tabular}{llllll}
\hline & KR & LR & VR & RR & ZR \\
\hline Solar irradiation, $\mathrm{kWh} / \mathrm{m}^{2}$ year & 1180 & 1149 & 1121 & 1155 & 1154 \\
Wind speed, $\mathrm{m} / \mathrm{s}$ year & 7.2 & 7.1 & 6.9 & 7 & 7.1 \\
Low quality wood, $\mathrm{t} / \mathrm{km}^{2}$ year & 1908 & 1259 & 1895 & 1905 & 1493 \\
Manure resource, dry material $\mathrm{t} / \mathrm{km}^{2}$ year & 16 & 14.1 & 13.9 & 17.1 & 35.4 \\
Straw resources, dry material $\mathrm{t} / \mathrm{km}^{2}$ year & 18.7 & 11.5 & 9.7 & 12.5 & 32.2 \\
Sewage sludge resources, $\mathrm{t} / \mathrm{km}^{2}$ year & 0.17 & 0.26 & 0.27 & 0.35 & 0.18 \\
\hline
\end{tabular}

\subsection{Distribution of Energy Generation and Consumption}

Table 3 summarizes information on the electricity generation capacities installed in 2017 by fuel consumed. The Table includes information on cogeneration plants, wind farms and hydropower plants in different planning regions. Fig. 4 shows the proportional distribution of the used resources in each region. Information on the amount of electricity produced in the largest cogeneration plants with a capacity exceeding $20 \mathrm{MW}$ and receiving payment for the installed capacity of the feed-in amounts is compiled from publicly available annual reports (see Table 4), [30] emission and fuel consumption reports. It is evident that the amount of electricity produced in the largest stations has significantly decreased in 2017 and increased in 2018.

The amount of heat produced in district heating and transferred to users in different regions and the installed heat capacities are taken from the Central Statistical Bureau database [29]. Fig. 3 shows that most heat is produced in RR by using natural gas cogeneration. The highest share of RES in the district heating sector has been achieved in VR by using wood biomass.

TABLE 3. INSTALLED ELECTRICAL CAPACITY (MW) BY TYPE OF ENERGY RESOURCES IN 2017 [31]

\begin{tabular}{lccccc}
\hline & KR & LR & VR & ZR & RR \\
\hline Gas & 8.16 & 33.64 & 5.97 & 37.11 & 1080.13 \\
Biomass & 10.52 & 6.65 & 19.43 & 12.62 & 21.14 \\
Biogas & 10.43 & 7.16 & 10.35 & 15.44 & 18.14 \\
Wind & 63.72 & 0.00 & 0.00 & 0.50 & 0.00 \\
HES & 4.16 & 5.80 & 9.47 & 914.28 & 644.49 \\
\hline
\end{tabular}




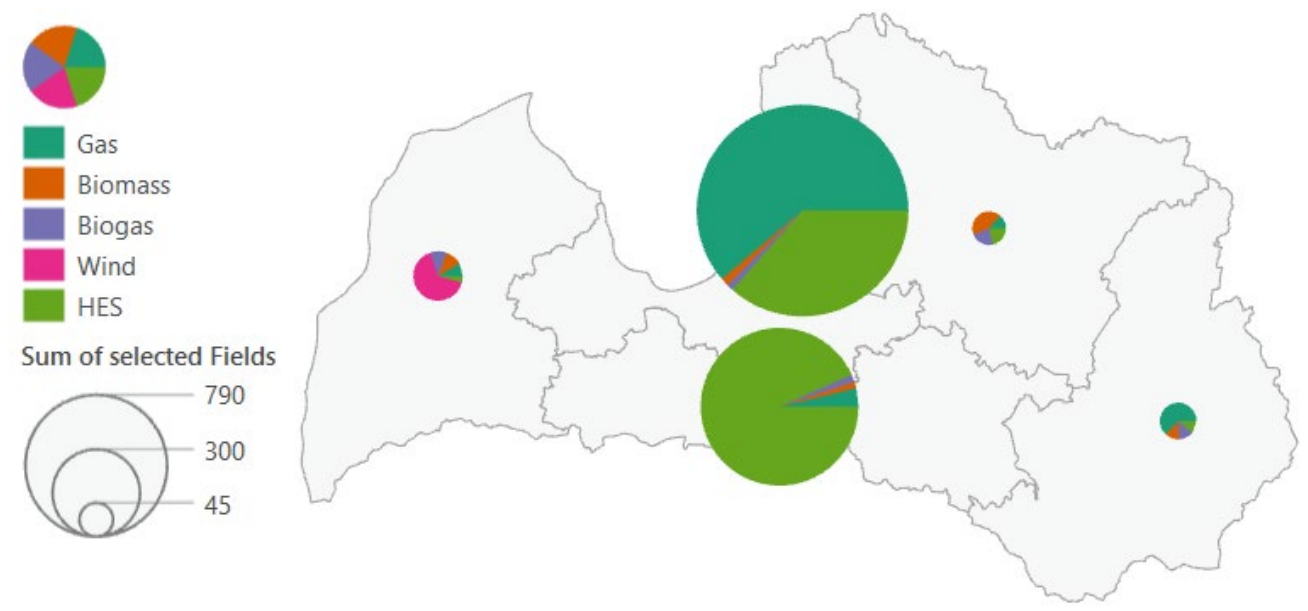

Fig. 3. Installed electrical capacity (MW) by type of energy resources used in 2017 [31].

TABle 4. Volume of Electricity (GWh/YeAR) Purchased Under MANDATORY PROCUREMENT IN 2017 [31]

\begin{tabular}{llllll}
\hline & KR & LR & VR & ZR & RR \\
\hline Gas & 50.83 & 208.14 & 20.51 & 69.26 & 2511.77 \\
Biomass & 65.93 & 31.90 & 118.76 & 71.09 & 108.95 \\
Biogas & 54.90 & 37.47 & 54.13 & 115.26 & 103.08 \\
Wind & 134.87 & 0.00 & 0.00 & 0.33 & 0.00 \\
HES & 9.44 & 21.54 & 34.32 & 2451.35 & 1849.42 \\
\hline
\end{tabular}

Data on installed solar power plants obtained from solar panel installation permits issued by the Ministry of Economics in the period from 2014 to 2018 (see Table 5) [32] have been compiled separately. It is assumed that installed stations have been installed in the year following the receipt of the permit. The Table 5 shows that the largest installed capacity of solar panels is in the RR. It shows the distribution by the sectors, so it is possible to estimate that kind of the legislative and social action would be the most successful for the promotion of the solar energy. More solar panels are being installed in the service sector, it is also the largest sector to use solar energy.

Changes in the energy habits such as switching to RES in the households are a significant social factor to indicate the tendencies in the energy sphere. Household electricity consumption in densely populated areas was determined from the information available in the Geospatial Planning Platform of the Administrative Territorial Reform [33]. The output data is compiled on the maps. The calculated consumption is summarized in Table 6. 
Table 5. Solar Panel Installation Permits (MW) FOR the Period From 2014 to 2018 [31]

\begin{tabular}{lccccc}
\hline & Agriculture & Production & Services & Central heating & Households \\
\hline KR & 0.4 & 0.0 & 0.5 & 0.0 & 0.5 \\
LR & 0.1 & 1.1 & 1.6 & 0.0 & 0.2 \\
RR & 0.2 & 0.3 & 5.5 & 4.0 & 1.2 \\
VR & 0.0 & 0.2 & 0.0 & 0.0 & 0.2 \\
ZR & 0.0 & 0.0 & 0.0 & 0.0 & 0.2 \\
\hline Total & 0.7 & 1.6 & 7.6 & 4.1 & 2.1 \\
\hline
\end{tabular}

TABle 6. ENERGy CONSUMPtion (GWH) In HOUSEHOLdS By REGIONS [33]

\begin{tabular}{llllll}
\hline Region & KR & LR & RR & VR & ZR \\
\hline GWh & 218.76 & 181.73 & 1059.17 & 140.31 & 192.78 \\
\hline
\end{tabular}

Fig. 4 shows the consumption of primary resources in the manufacturing sector in 2017 which is the highest in RR, where biomass is used the most, but coal is used more in KR than in other regions.

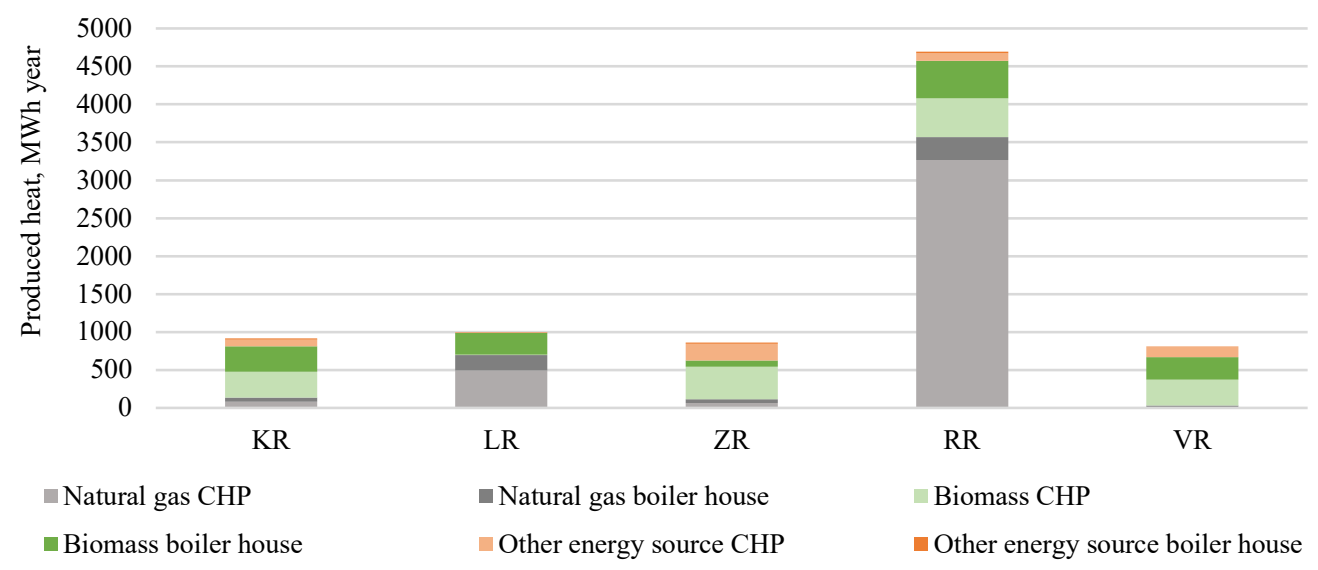

Fig. 4. Heat produced by fuel types and technologies in 2017 in different planning regions [31].

Fig. 5 and Fig. 6 summarize the total consumption of primary resources in the manufacturing and services sectors. The obtained data on the total consumption of natural gas and biomass in these sectors have been adjusted per the available information in the total energy balance. According to the data of 2017, the RR consumes five times more resources in the service and public sector than the KR. KR, LR and VR have a predominance of biomass, while ZR uses natural gas slightly more. Most of the companies in Riga use natural gas as an energy resource. 


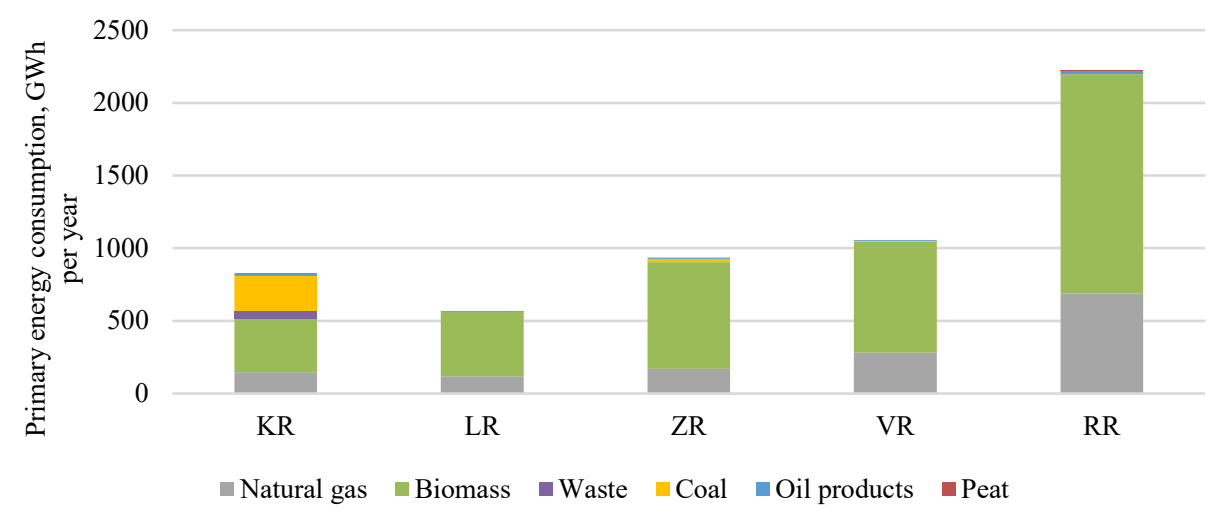

Fig. 5. Distribution of primary resource consumption in the manufacturing sector in 2017 [31].



Fig. 6. Distribution of primary resource consumption in services and public sector in 2017 [31].

The obtained regional profiles of the energy sector can be further used as input data in more complex mathematical models. The results show that the current energy consumption and production capacities from fossil fuels are concentrated in RR; therefore, significant focus should be placed to eliminate the use of natural gas in this region by seeking RES technologies that could provide baseload coverage.

\section{Conclusions}

The study identifies regional energy profiles by considering the potential of different RES, existing heat and power generation technologies, energy consumption and limitations for wind energy use. GIS visualization is best used with the spatially divided data into more groups or tightly depending on the spatial components. It is not the case if we only observe the planning region level, but it will be beneficial in future works where counties or municipalities are surveyed.

The results show that KR has a higher potential for variable energy sources (solar and wind) and biomass. Still, ZR has a high potential for agricultural residues, which is already used for biogas production and could cover energy demand in the future. In LR and VR, the potential 
for different available resources is lower; however, these regions indicate a high share of RES in various sectors, mainly due to the use of biomass. Further assessment would be necessary to identify potential cooperation among regions and municipalities to satisfy the growing biomass demand.

The highest energy consumption and the highest installed power and heat generation capacities are in RR due to the higher population density in Riga. The existing combined heat and power (CHP) plants are operating by using natural gas. Therefore, more complex simulations should be necessary to identify potential technological solutions to eliminate fossil fuel use in this region.

There is a lot of territory with shrubs along ditches and on uncultivated or unused fields, which could be a potential source of raw material for energy wood, saving the material that can be turned into a product with added value. At the regional level, installing modern wood processing equipment and setting up production facilities that allow wood waste or scrap to be converted into energy wood is possible and contributes to economic growth. There is a potential to develop a network of interconnected municipalities that could exchange the energy wood and well-organized logistics and a large enough warehouse for energy wood storage. Municipalities with a large part covered by forests can promote their development by close cooperation with private forest owners and the joint stock company 'Latvian State Forests' to ensure sustainable forest development [34].

In Latvia, most of the data sets, especially those collected and processed in a centralized way for the whole country and those publicly available, are generalized for the entire territory. At the same time, regions tend to have data that they collect themselves. There is a lack of guidelines regarding collecting and publishing; data is available mainly due to the local administration's voluntary initiative, primarily aiming to attract investors or tourists, or due to publicity requirements of the funding institutions for specific projects. Such information might be helpful; however, there are no centralized guidelines regarding the collecting and processing of the data that would be binding for all regions, which means that information is not available for all regions to an equal extent. In other cases, data are not comparable due to the different processing methods and different levels of precision.

Analysis at the regional level provides a simplified insight into the distribution of resources in Latvia and can help plan development at a regional scale. During the research different information databases and data analyses methods have been used to determine the spatial profile of RES potential, heat and power generation and consumption.

It is essential to identify the existing energy sources of fossil and RES to assess opportunities for renewable energy development. Given that the potential of RES is affected by spatially changing conditions, it is helpful to use a mapping method for this purpose. The obtained regional profiles and identified limitations for a particular RES can be further used in more advanced modelling tools, such as system dynamics modelling, linear programming models, etc.

The study shows that spatial analyses are necessary even in relatively small countries like Latvia to better identify bottlenecks and barriers to achieving green transformations in the energy sector. When evaluating the shift from fossil fuels to RES without considering regional differences, it is impossible to fully understand the most suitable technological solutions for further development in the national context. The proposed methodology, which uses different databases and spatial analyses for regional profile development, can be adjusted and applied to other countries. 


\section{ACKNOWLEDGEMENT}

The research is funded by the Ministry of Economics of the Republic of Latvia, project “Assessment of Latvia's renewable energy supply-demand economic potential and policy recommendations", project No. VPPEM2018/AER_1_0001.

\section{REFERENCES}

[1] Dobrotkova P., Suranab K. The price of solar energy: Comparing competitive auctions for utility-scale solar PV in developing countries. Energy Policy 2018:118:133-148. https://doi.org/10.1016/j.enpol.2018.03.036

[2] Aslani A., Helo P., Naaranoja M. Role of renewable energy policies in energy dependency in Finland: System dynamics approach. Applied Energy 2014:113:758-765. https://doi.org/10.1016/j.apenergy.2013.08.015

[3] Resch B., et al. GIS-Based Planning and Modelling of Renewable Energy: Challenges and Future Research Avenues. ISPRS International Journal of Geo-Information 2014:3(2):662-692. https://doi.org/10.3390/ijgi3020662

[4] Ieviņa L., et al. Mapping of Distributed Power Generation Versus Biomass Availability. 2019 IEEE 60th International Scientific Conference on Power and Electrical Engineering of Riga Technical University (RTUCON), Riga, Latvia, 2019. https://doi.org/10.1109/RTUCON48111.2019.8982373

[5] Peck A., et al. Water Resources Research Report Coupling System Dynamics with Geographic Information System. London: University of Western Ontario, 2014.

[6] Grāvelsiņš A., et al. Solar Power in District Heating. P2H Flexibility Concept. Energy 2019:181:1023-1035. https://doi.org/10.1016/j.energy.2019.05.224

[7] Ehrlich L., et al. The potential of decentralized power-to-heat as a flexibility option for the German electricity system: A microeconomic perspective. Energy Policy 2015:87:417-428. https://doi.org/10.1016/j.enpol.2015.09.032

[8] Spataru C. Whole Energy System Dynamics: Theory, modelling and policy. London: Routledge, 2017.

[9] Goodchild M. F. GIS and Modeling Overview. GIS, Spatial Analysis, and Modeling. CA: ESRI Press, 2005.

[10] Lund H., et al. Estonian energy system Proposals for the implementation of a cogeneration strategy. Energy Policy 2000:28(10):729-736. https://doi.org/10.1016/S0301-4215(00)00048-3

[11] Gravelsins A., et al. Modelling energy production flexibility: system dynamics approach. Energy Procedia 2018:147:503-509. https://doi.org/10.1016/j.egypro.2018.07.060

[12] Litgrid, AST, elering. Review of RES perspective in Baltic countries till 2030. Riga: AST, 2015.

[13] Technical University of Denmark, World Bank Group. Global Wind Atlas [Online]. [Accessed 01.03.2021]. Available: https://www.globalwindatlas.info/

[14] European Commission. Photovoltaic geographical information system [Online]. [Accessed 01.03.2021]. Available: https://ec.europa.eu/jrc/en/pvgis

[15] Valsts meža dienests. Meža statistikas CD (Forest statistics CD) [Online]. [Accessed 01.03.2021]. Available: https:/www.vmd.gov.lv/valsts-meza-dienests/statiskas-lapas/publikacijas-un-statistika/meza-statistikascd?nid=1809\#jump (in Latvian)

[16] Townsend P. Forest Biomass of Living, Merchantable Trees in Nova Scotia. Nova Scotia: Nova Scotia Department of Natural Resources, 2008.

[17] LVGMC. Latvia's National Inventory Report 1990-2017. Riga: LVGMC, 2019.

[18] Asveld L., et al. Getting to the core of the bio-economy: A perspective on the sustainable promise of biomass. Hague: Rathenau Institute, 2011.

[19] Lauksaimniecības datu centrs. Publiskā datu bāze (Agricultural Data Center. Public database) [Online]. [Accessed 01.03.2021]. Available: http://pub.ldc.gov.lv/pub_stat.php?lang=lv (in Latvian)

[20] Ministry of Agticulture Republic of Latvia. Kūtsmēēlu ieguve un apsaimniekošana. Uzn̄ēmumu tehniskie noteikumi (nozares standarts) (Manure extraction and management. Company technical regulations (industry standard)). Riga: MoA, 2008.

[21] Ministry of Economics Republic of Latvia. Energétikas stratēgija 2030 (Energy Strategy 2030). Riga: MoE, 2011. (in Latvian)

[22] Mohammadi M., Harjunkoski I. Performance analysis of waste-to-energy technologies for sustainable energy generation in integrated supply chains. Computers \& Chemical engineering 2020:140(2):106905. https://doi.org/10.1016/j.compchemeng.2020.106905

[23] LVGMC. 2-Gaiss datubāze (2-Air database). [Online]. [Accessed 01.03.2021]. Available: http://parissrv.lvgmc.lv/\#viewType=airReports\&incrementCounter=1 (in Latvian)

[24] Cabnet of Ministers. Noteikumi no 23.05. Nr. 271. Noteikumi par vides aizsardzības oficiālās statistikas un piesārṇojošās darb̄̄ibas pārskata veidlapām (Regulations from 23.05. Nr 271. Provisions on official environmental protection statistics and pollution activity report forms). Latvijas Vēstnesis 2017:103. (in Latvian) 
[25] Central Statistical Bureau Republic of Latvia. NACE: Saimniecisko darbību statistiskā klasifikācija Eiropas Kopienā (NACE: Statistical Classification of Economic Activities in the European Community) [Online]. [Accessed 01.03.20201]. Available: https://www.csb.gov.lv/en/classification_meta/3 (in Latvian)

[26] Saeima. Aizsargjoslu likums. Latvijas (Protection zones law). Latvijas Vêstnesis 1997:56/57. (in Latvian)

[27] Technical University of Denmark. Global Wind Atlas [Online]. [Accessed 01.03.2021]. Available: https://www.globalwindatlas.info

[28] Latvijas Biogāzes asociācija. Biogāzes attīstība Latvijā. 2013. [Online]. [Accessed 01.01.2019]. Available: http://latvijasbiogaze.lv/?c=3

[29] Central Statistical Bureau. CSP datubāze (CSB Database) [Online]. [Accessed 01.03.2021]. Available: https://www.csb.gov.lv/lv/statistika/db (in Latvian)

[30] LSM.lv. Latvenergo pārliecināts, ka elektromobilị ir nākotne; atver jaunas uzlādes stacijas (Latvenergo is convinced that electric cars are the future; opens new charging stations.). 2019 [Online]. [Accessed 10.03.2021]. Available: https://www.lsm.lv/raksts/zinas/ekonomika/latvenergo-parliecinats-ka-elektromobili-ir-nakotne-atver-jaunas-uzladesstacijas.a330261/ (in Latvian)

[31] Ministry of Economy Republic of Latvia. Informācija par izdotajiem lēmumiem par elektroenerǵijas obligāto iepirkumu (Information on issued decisions on mandatory electricity procurement.). 2020. [Online]. [Accessed 10.03.2021]. Available: https://em.gov.lv/lv/nozares_politika/atjaunojama_energija_un_kogeneracija/informacija_par izdotajiem_lemumiem_par_elektroenergijas_obligato_iepirkumu/(in Latvian)

[32] Cabinet of Ministers. Rīkojums no 17.07. Nr. 381 "Par konceptuālo zinojumu "Par bezmaksas emisijas kvotu piešḳiršanu elektroenerǵijas ražotājiem Eiropas Savienības emisiju tirdzniecỉbas sistēmas 2021.-2030. gada periodā"'" (Order from 17.07. No. 381 "On the Conceptual Report" On the Allocation of Free Emission Allowances to Electricity Producers of the European Union Emissions Trading Scheme 2021-2030. during the year). Latvijas Vēstnesis 2019:148. (in Latvian)

[33] VARAM. Administratīvi teritoriālās reformas pamatojuma un administratīvi teritoriālās reformas geotelpiskās plānošanas platforma (Development of the justification of the administrative-territorial reform and the geospatial planning platform of the administrative-territorial reform.). [Online]. [Accessed 10.03.2019]. Available: https://www.varam.gov.lv/lv/iepirkums/administrativi-teritorialas-reformas-pamatojuma-un-administrativiteritorialas-reformas-geotelpiskas-planosanas-platformas-izstrade

[34] Vidzemes plānošanas regiions. Reǵionālais profils energoapgādes, patēriṇa un energopārvaldības jomā (Regional profile in energy supply, consumption and energy management). Cesis: VPR, 2018. (in Latvian) 